\title{
Truth or reconciliation? A response to Theo de Wit
}

\begin{abstract}
In my response to Theo de Wit's paper, I first set out what I consider to be his most important claims about the relationship between evil and narrativity, before asking four questions about some of the implications of these claims: (1) Are we to presume that there is an absolute choice between reconciliation and a full recounting of evil, so that the latter would necessarily preclude the former? (2) Assuming that we are indeed faced with such a choice, what is proper response to it? (3) Is there any hope of a trustworthy account of evil at all, given that deception seems to be endemic in every such account? and (4) What status should we accord to victimhood in general and victims' narratives in particular?
\end{abstract}

This article is a response to Theo de Wit's argument in "The adornment of evil. Narrativity, evil, reconciliation". I will begin by saying what I take De Wit's paper to be about - or at least, what I consider to be the most important claims that make up his argument - before raising four specific questions that result from these claims.

In the most general terms, De Wit's topic is the problem of evil - particularly, how we are to think and talk about evil, and how we are to live with one another and ourselves in its aftermath.

To think and talk about evil is not merely to acknowledge that it exists. Rather, it involves telling the story of evil deeds in one form or another, putting them into a narrative, giving an account of them.

But this is precisely where the difficulty arises, for a coherent narrative of evil always runs the risk of putting evil in its place, so to speak - which is to say, making it more understandable, and hence more palatable to us, easier to live with, perhaps even easier to bear. A narrative account of evil, in so far as it presents even the greatest atrocities as subject to reasons, situated within a particular time, related to particular circumstances, may all too easily diminish or explain away the actual iniquity of these deeds and events.

This seems to me to lie at the heart of De Wit's concern: How can we understand evil, come to grips with it, tell the story of evil having been done, without thereby diminishing it, or reconciling ourselves to it - in other words, without making it somehow less evil?

The problem is compounded by the fact that, where the evil is our own, we are inclined towards self-deception. That is to say, we tend to tell the story of our own misdeeds in such a way as to cast them in a better light, so that they appear - to others and to ourselves - as having been excused and justified from the beginning.

So, this is the difficulty: On the one hand, any attempt to understand evil, to come to grips with it, involves a narrative account of how it has come to be. On the other hand, in so far as such narratives can make evil all-too-understandable, even justified, they often are barriers to a proper confrontation with actual evil. Paradoxically, then, the attempt to understand the phenomenon of evil can prevent the very understanding it seeks.

This difficulty is most visibly present in the realm of politics, where the problem of evil is not merely a matter of the heart, but a matter of how we live with one another in the world. De Wit then goes on to examine three narratives of evil, each of which has served either to explain and justify certain political misdeeds, or to reconcile us to them. 
The first is a backward-looking narrative, where misdeeds in the present are cast in the vocabulary of the great and monumental deeds of the past - as an extension of the founding violence of those who originally established a particular nation or political order.

The second is a forward-looking narrative, where atrocities committed towards certain inhabitants of a state are presented as part of a world-historical process that will ultimately culminate in the reign of justice. So, evil now or in the past, but for the sake of a future without evil.

The third example is more complicated, and at the same time more pertinent to us in this country. It involves a seemingly more honest attempt to confront past evil by allowing perpetrators and victims to tell of what was done to them and by them, and to do so in a public forum. This is of course the model of the Truth and Reconciliation Commission.

Unlike in the first two examples, the purpose of the TRC - on the face of it - was not to justify, excuse, or explain away political misdeeds, either by casting them in the vocabulary of past greatness or by appealing to a world-historical process. In this case, the victims had a voice, and could tell us what really happened to them, while evildoers had an incentive to tell the truth about their deeds, since this would qualify them for amnesty.

Nevertheless, as De Wit points out, the TRC process did serve a purpose beyond merely coming to grips with past evil, which was to effect political reconciliation. This is already evident from the founding law of the TRC, which is known as the Promotion of National Unity and Reconciliation Act. From its inception, telling the truth about evil was to be instrumental in reconciliation and nation building. The truth shall set you free, as Desmond Tutu so often said to those who appeared before the commission: free from the burden of past evil-doing or suffering, and therefore free to sincerely embrace, unite, reconcile with one's fellow citizens, be they former perpetrators or victims.

If I read De Wit correctly, he is suggesting that this reconciliation has been at best premature and at worst, an illusion, in so far as it was based on deception. Given that the accounts of evil doing before the TRC were made to serve a new political building project, individual narratives of evil did not stand for what they were. They were always to be understood against the background imperative to reconcile. For this reason, there was selective pressure to allow, disseminate and remember - as well as to question and probe - only those accounts that did in fact serve this imperative. Hence certain evils and atrocities were spoken into silence; others never got a hearing.

The TRC, then, was an attempt to confront past evil in order to effect reconciliation, but it depended on deception regarding some of the very evils that made reconciliation necessary in the first place. If one wanted to draw a very bleak conclusion from De Wit's argument, it would be that the TRC, for all its attempts to come to grips with the misdeeds of the past, brought neither justice for the victims nor reconciliation for the country at large.

Assuming I have understood the argument correctly, let me now move on to some of the questions called up by De Wit's analysis of the link between evil, narrativity and deception.

My first question is whether we should take the failure of justice and reconciliation in the aftermath of political evil to be inevitable. It seems to me - at least in the way De Wit has portrayed the problem - that we are confronted here by an insurmountable either/or: Either we do justice to the victims by recounting the evil that was done in its fullness and severity, or we agree to forget, to overlook or to suppress at least some of the worst things that were done - for the sake of reconciliation. Or is there a third way? A way of coming to grips with past evil without deception, and yet, somehow still achieving reconciliation? What would be the conditions for the realization of such a possibility?

Secondly, given the choice between an unmitigated recounting of evil on the one hand, 
and reconciliation - even sham reconciliation - on the other, which is better? Is honesty about evil, assuming that it is possible, necessarily preferable to hypocrisy - especially in the political domain?

This leads to my third question, which really follows from the first two, but now directed at De Wit's argument as a whole: Is there any hope of a trustworthy account of evil at all, given that deception seems to be endemic in every such account? How are we to think and talk about evil so that we may understand it, without this involving either self-deception or mitigation?

One answer to this question might be: Let the victims speak. But, and this is my fourth and last question, why would we assume that victimhood is a guarantee against self-deception? While it is relatively easy to recognize that we have a tendency towards self-deception regarding our own misdeeds, it doesn't seem beyond the realms of possibility that we might deceive ourselves about the nature and extent of our victimhood too. De Wit points out that our narrative understanding of the world tends to run away with us precisely when our deepest fears and longings are at stake. But again, this would hold as much for victims as for perpetrators. In light of this possibility, we have to ask: what would it mean to do justice to the victims of evil deeds? Would it mean to accept their own narratives without question? If yes, why would that be? If not, what is the alternative?

These are the questions that presented themselves to me in reading Theo De Wit's paper. This doesn't mean that he should necessarily be able to answer them in a heartbeat. Rather, they seem to me the kinds of questions that necessarily confront any attempt to think through the problem of reconciliation in the aftermath of evil.

In conclusion, then, let me thank him for his paper, in which he confronts us with the very intractability of the problem of evil. Of course, we might prefer not to think and talk about it at all, so that it remains some unexamined, monstrous thing hovering beyond the limits of our understanding. We might, in this way, avoid explaining it away, or deceiving ourselves about it. We will not, however, be in a position to prevent or resist or overcome it.

So, Theo, for making us face up to the difficult, but morally and politically important task of thinking through the problem of evil, thank you very much. 